\title{
EFFECT OF MICROBIAL INOCULATION ON REDUCTION OF COWPEA (Vigna unguiculata, L. Walp) CHEMICAL FERTILIZERS UNDER NEWLY RECLAIMED SOILS CONDITION IN EGYPT
}

Abdel-Aziz, M. A. ${ }^{1}$ and M. F. Salem ${ }^{2}$

1-Veg. Res. Dept., Hort. Res. Inst., Agric. Res. Center, (A. R. C.), Giza, Egypt

2- Organic Agric. Res. Unit., Dept. of Environmental Biotechnology., Genetic Engineering and Biotechnology Res. Institute, GEBRI, Sadat City Minufiya University, Egypt.

\begin{abstract}
This research was conducted during the two summer seasons of 2009 and 2010 at South Tahrir, Experimental Farm of Horticulture Research Institute, Agriculture Research Center (A R C), Beheira, Governorate, Egypt. This study carried out to evaluate the possibility of using different rates of biofertilizer instead a part of chemical fertilizers for optimal nutrition and some attributes of cowpea. The chemical fertilizers were as four levels of recommended fertilization doses of $\mathrm{N}, \mathrm{P}$ and $\mathrm{K}$ fertilizers i.e. 0 , 50,75 and $100 \% /$ fed. Five treatments of microbial inoculations (biofertilizer) i.e. without microbial inoculation (B0), inoculations with Azospirillum sp. and Trichoderma sp. for nitrogen (B1), Bacillus megaterium for phosphorus (B2), Pseudomonas fluorescens for potassium (B3) and the mixtures of all previous of microbial inoculations (B4).

The obtained results indicated that there were gradually significant increases due to fertilize cowpea plants with $75 \%$ from the recommended fertilization on various obtained characters. Also, treating seeds of cowpea with the mixtures of all microbial inoculations of Azospirillum sp. and Trichoderma sp., as well as Bacillus megaterium and Pseudomonas fluorescens markedly enhanced effect on cowpea growth, total dry seed yield (ton/ fed.) and pod characters, nitrogen (\%), phosphorus (\%), potassium (\%) content in leaves as well as protein (\%) content in seeds.

The interactions between application of the $75 \%$ recommended fertilization and treating cowpea seeds by mixtures of all microbial inoculations helped in producing the most pronounced effects of all vegetative growth characters, total dry seed yield (ton/ fed.), pod characters, nitrogen, phosphorus, potassium content (\%) in leaves and protein content (\%) in seeds. Seed inoculations with individual Azospirillum sp. and Trichoderma sp. obtained the superiority treatment for vegetative growth characters and nitrogen (\%) in leaves and protein content (\%) in seeds. Seed inoculations with individual Bacillus megaterium and individual Pseudomonas fluorescens obtained the most effective treatment for total dry seed yield (ton/ fed.), pod characters, phosphorus (\%) and potassium content (\%) in leaves, respectively when compared to the control untreated plants.
\end{abstract}

\section{INTRODUCTION}

Cowpea (Vigna unguiculata, L. Walp) is a member of family fabace and considered as one of the important vegetable crops in Egypt, seeds represent a chief source of protein and carbohydrates content. Also, cowpea it can grow easily in the new reclaimed lands. The protein in cowpea seed is rich in 
amino acids, lysine and tryptophan compared to cereal grains (Santos, 2000). Nutrients are required by plant in adequate quantities for metabolic regulation, production of new tissues as well as development. They are structural components of metabolic and prototoplasm structure (Adelusi and Aileme, 2006).

Plant nutrition is one of the most important factors that increase plant production. Nitrogen is one of the major elements for plants growth and development that has an important role in plant nutrition and therefore is the yield-limiting factor for plant growth in many areas especially in low organic soils. Nitrogen is required in large amounts for plant growth, since it is the basic constituent of many chemical compounds, including proteins and nucleic acids (Rashid et al., 1999 and Najafva et al., 2008). In this connection, El-Bably and El-Waraky (2006) suggested that application of $\mathrm{N}$ fertilizers increased vegetative growth character as well as yield and its components of cowpea plant fertilized with $30 \mathrm{Kg} / \mathrm{fed}$. produced the greatest pod yield. On the other hand, Abayomi et al. (2008) stated that phosphorus does not only increase seed yields but also nodulation and thus $\mathrm{N}$ fixation. Phosphorus application influences the contents of other nutrients in cowpea leaves and seeds (Kang and Nangju, 1983). Phosphorus has also been reported to increase the number of leaves and fruits per plant, as well as earliness of flowering and yields. However, inorganic P-fertilizers are often expensive and not readily available to resource - poor farmers.

Furthermore, P-fertilizer can be fixed into unavailable forms to plants such as Fe and Al oxides in tropical soils (Sample et al., 1980). Application of inorganic $P$ fertilizers may thus not be the most viable option to alleviate $P$ deficiency for improving cowpea production. Effects of $P$ on nodulation (Ankomah et al., 1995) and yield (Sanginga et al., 2000) of cowpea have been previously reported to vary with genotypic. Moreover, plants fertilized with high levels of phosphorus survived successive periods of drought. These took root growth that allowed them to explore the large amount of water existing in the root zone in addition to possessing a greater capacity to extract water due to greater hydraulic conductivity of root (Chiulele, 2003). Sivak and Walker (1986) mentioned that phosphorus application adds the assimilative capacity of the plants by increasing the leaf area or photosynthetic activity, ensuring an effect on the roots. Benton (1998) recorded that potassium is required for the accumulation and translocation of newly formed carbohydrates. Potassium plays a key role, since it is involved in metabolic processes, such as the synthesis of proteins, enzyme activation, membrane transport processes, charge balance and the generation of turgor pressure (Dorais et al., 2001 and Achilea et al. 1999) working on tomato plants, recorded that, potassium is found a free state in cell vacuole, so it plays a great role in water absorption and movement within the plant, consequently, affects cell turgidity as well as leaf expansion, also, it affects carbohydrates biosynthesis and mobilization from part to another.

In the last decade biofertilizers were used extensively as an eco-friendly approach to minimize the use of chemical fertilizers, improve soil fertility status and enhance crop production by their biological activity in the rhizosphere. Bio-organic farming today has become of great importance for 
sustainable agriculture, limiting deterioration of the agricultural lands and environment, producing safer crop products for human and animal consumption and increasing possibility of biological control of harmful insects and soil-borne pathogens (Gomaa and Abou-Aly, 2001). These microorganisms are able to promote proper circulation of plant nutrients, which are capable of mobilizing important nutritional elements in the soil from non-usable to usable form by the crop plants through their biological processes and reduce the need for chemical fertilizers. Biological nitrogen fixation is a key factor to sustain agricultural productivity. Increasing crop yield cannot be fulfilled unless we carefully make use of biological nitrogen fixation. Since the nodulation is solely a physiological process, it can be induced by using different plant growth regulators. In this process nitrogenfixing bacteria enter plant through its root hairs where the nodules will be formed. These nodules can provide a niche for the bacteria to fix atmospheric nitrogen. They not only fix atmospheric nitrogen but also produce certain plant growth promoting hormones (Frankenberger and Arshad, 1995). These bacteria belong to several genera including Azotobacter, Azospirillum, Bacillus, Arthrobacter, Enterobacter, Pseudomonas, Alcaligenes and Klebsiella Azotobacter has been reported to fix not only atmospheric nitrogen but also produce plant growth regulators which antagonize plant pathogens Azotobacter is a free living nitrogen-fixing bacterium. It is used as a biofertilizer in growing many crop plants.

In this connection, phosphate solubilizing microorganisms play a key role in the plant metabolism and crop productivity. They have been reported to increase the availability and uptake of native soil phosphorus by converting insoluble phosphates to soluble forms by producing various organic acids (Raja et al., 2002). Free living nitrogen fixing bacteria such as Azotobacter and Azospirillum have the ability not only to fix nitrogen but also to release certain phytohormons of $\mathrm{GA}_{3}$, IAA and cytokinins which increased the surface area per unit root length and enhanced root hair branching with an eventual increase in the uptake of nutrients from soil nature which could stimulate plant growth, absorption of nutrients and photosynthesis process (Abdel-Latif et al., 2001).

This research was conducted to study the possibility of using different kinds of biofertilizers, instead of a part of chemical fertilizers and environmental pollution for optimal nutrition of cowpea and its some attributes. Also, to integrating chemical fertilizers levels of $\mathrm{N}, \mathrm{P}$, and $\mathrm{K}$ with 75 $\%$ from the recommended fertilization and microbial inoculations in both individually or in combination has been found to be quite promising not only in maintaining higher growth and productivity but also in improving pod characters and quality.

\section{MATERIALS AND METHODS}

The experiment was carried out at South Tahrir, Experimental Farm of Horticulture Research Institute, Agriculture Research Center (A R C), 
Beheira, Governorate, Egypt during the two summer seasons of 2009 and 2010.

Soil samples were taken from $30 \mathrm{~cm}$ soil surface to determine the physical and chemical properties of the experimental soil presented in Table 1.

Table 1: Physical and chemical properties of the experimental soil during the two lat summer seasons 2009 and 2010 seasons.

\begin{tabular}{|c|c|c|c|c|c|c|c|c|c|c|c|c|c|c|}
\hline \multirow{3}{*}{ Seasons } & \multicolumn{4}{|c|}{ Physical properties } & \multicolumn{10}{|c|}{ Chemical properties } \\
\hline & \multirow{2}{*}{$\begin{array}{c}\text { Sand } \\
(\%)\end{array}$} & \multirow{2}{*}{$\begin{array}{l}\text { Silt } \\
(\%)\end{array}$} & \multirow{2}{*}{$\begin{array}{l}\text { Clay } \\
(\%)\end{array}$} & \multirow[t]{2}{*}{ Texture } & \multirow{2}{*}{$\begin{array}{c}\mathrm{EC} \\
\mathrm{dSm} \mathbf{m}^{-1}\end{array}$} & \multirow[t]{2}{*}{$\mathbf{P H}$} & \multicolumn{4}{|c|}{$\begin{array}{l}\text { Soluble cation } \\
\left.\text { (meg }{ }^{1-1}\right)\end{array}$} & \multicolumn{3}{|c|}{$\begin{array}{c}\text { Soluble anion } \\
\left(\text { meg }^{1-1}\right)\end{array}$} & \multirow{2}{*}{$\begin{array}{l}\text { Total } \\
\mathrm{N} \%\end{array}$} \\
\hline & & & & & & & $\mathbf{P}^{++}$ & $\mathrm{Co}^{++}$ & $\mathrm{Mg}^{++}$ & $\mathrm{K}^{+}$ & $\mathrm{HCO}_{3}^{-}$ & $\mathrm{Cl}^{-}$ & $\mathrm{So}_{4}^{-}$ & \\
\hline 2009 & 94 & 4 & 2 & Sand & 0.21 & 8.9 & 0.16 & 0.72 & 0.57 & 0.20 & 0.55 & 0.42 & 0.57 & 0.010 \\
\hline 2010 & 92 & 5 & 3 & Sand & 0.17 & 8.8 & 0.15 & 0.75 & 0.54 & 0.19 & 0.57 & 0.43 & 0.56 & 0.008 \\
\hline
\end{tabular}

\section{Layout of the experiment and treatments:}

The experiment contained 20 treatments, were combination between NPK levels and some biofertilizer treatments as follows:

A. N, P and K levels:

1 - $0 \%$ NPK.

2- $50 \%$ recommended dose NPK $\mathrm{Kg} / \mathrm{fed}$.

3- $75 \%$ recommended dose NPK Kg /fed.

4- $100 \%$ recommended dose NPK Kg /fed.

B. Biofertilizer treatments:

$1-\mathrm{B} 0=$ uninoculated treatment (control).

2-B1 = Azospirillum sp. and Trichoderma sp. for nitrogen.

3-B2 = Bacillus megaterium for phosphorus.

4-B3 = Pseudomonas fluorescens for potassium.

$5-\mathrm{B} 4=$ mixtures of all previous.

These treatments were arranged in split plot design with three replications. $\mathrm{N}, \mathrm{P}$ and $\mathrm{K}$ levels treatments were assigned at random in the main plots, while sub plots were devoted to biofertilizer treatments. Nitrogen fertilizer application added as a form of ammonium sulphate $(20.6 \% \mathrm{~N})$ half of the recommended dose of nitrogen fertilizer added at three weeks after sowing and the equal dose after two weeks from the previous one. Phosphorus fertilizer application added as a form of superphosphate $(15.5 \%$ $\mathrm{P}_{2} \mathrm{O}_{5}$ ). Potassium fertilizer application added as a form of potassium sulfate $\left(50 \% \mathrm{~K}_{2} \mathrm{O}\right)$. Both phosphorus and potassium fertilizers application added (as a one dose) before sowing. The recommended fertilization doses used as (61.8 Kg N, $31 \mathrm{Kg} \mathrm{P}_{2} \mathrm{O}_{5}$ and $37.5 \mathrm{Kg} \mathrm{K} 2 \mathrm{O} /$ fed.). The experimental unite area was $15 \mathrm{~m}^{2}$ and contain 3 drippers lines, with $5 \mathrm{~m}$ length and $1 \mathrm{~m}$ width. Cowpea seeds (cv. Kaha-1) were sown on $7^{\text {th }}$ and $11^{\text {th }}$ of April in 2009 and 2010 , respectively in rows at both sides at $20 \mathrm{~cm}$ distance between hills. Two microbial inoculated seeds were sown and covered by sand soil in a hill using drip irrigation system. All other agricultural practices were conducted for this region as recommended by the Ministry of Agriculture in Egypt whenever were necessary. 


\section{Inoculation preparation:}

The Bacterial strains Azospirillum sp. and Trichoderma sp. (B1) for nitrogen, Bacillus megaterium (B2) for phosphorus and Pseudomonas fluorescens (B3) for potassium were kindly obtained from the Organic Agric. Research Unit, Department of Environmental Biotechnology, GEBRI, Sadat City, Minufiya University, Egypt. The nodule isolates and the reference strains were grown for $72 \mathrm{~h}$ in Yeast Mannitol Broth (YMB) according to the method mentioned by Vincent, 1970. Bacterial suspension prepared from 3-day-old culture was injected into sterilized vermiculite then left to dry before filling with peat moss media to inoculation with seeds. The inoculation rate was adding at $50 \%$ for seed inoculation and $50 \%$ at 15 days after planting.

\section{The following characters were recorded:}

\section{1- Vegetative growth characters:}

Three plants were taken randomly from each replicate at flowering and pod setting stage (50 days after sowing) to measure the following vegetative characters i.e. plant height $(\mathrm{cm})$, number of branches and leaves, fresh and dry weights/plant $(\mathrm{g})$.

\section{2- Total dry seed yield (ton/ fed.) and pod characters:}

A random sample of 10 dry pods at harvesting time from each replicate were taken to determine the following data: average pod length $(\mathrm{cm})$, average pod diameter $(\mathrm{cm})$, average number of seeds per pod, average weight of 100 seeds (seed index). Dry pods of all plants per plot were harvested and thrashed manually and total dry seed yield $(\mathrm{kg}) / \mathrm{plot}$ were determined to calculate total yield as ton/fed.

3- Chemical composition in leaves and protein content (\%) in seeds:

Fresh weight of foliage and seeds of cowpea were dried in an electric forced-air oven at $70^{\circ} \mathrm{C}$ to constant weight then fractionated and sifting. The fine powder $(0.2 \mathrm{~g})$ of dry sample was digested in a mixture of sulphuric and perchloric acids according to Piper (1947) to estimate total nitrogen in both foliage and seeds but phosphorus and potassium in foliage only (N, P and K) as wet digestion. Total nitrogen (\%) was determined by using the modified "Micro-Kheldahl" method apparatus of Parnas and Wagner as described by Pergl (1945). Total protein \% was calculated in seeds by multiplying nitrogen content (\%) by 6.25 . Phosphorus (\%) was estimated spectrophotometrically as described by King (1951). Potassium (\%) was determined using the Flamephotometr as described by Brown and Jackson (1955).

\section{4-Statistical analysis:}

All data were subjected to the statistical analysis of variance and treatment means were compared according to the Least Significant Differences ( $L S D$ at 0.05 ) test method as described by Snedecor and Cochran (1980). 


\section{RESULTS AND DISCUSSION}

\section{1-Vegetative growth characters of cowpea:}

\section{1-a- Effect of chemical fertilizers levels ( $N, P$ and $K$ ):}

Data illustrated in Table 2 exhibited as plant height, number of branches and leaves as well as fresh and dry weights/ plant obtained significant increases on vegetative growth characters with increasing the fertilization levels up to $75 \%$ from the recommended fertilization level which include the best characters i.e. tallest plants $(r q, \varepsilon-\varepsilon \varepsilon, \wedge \mathrm{cm})$, the highest number of branches $(\varepsilon, r-4.9)$ and leaves $(25.3-28.9)$, heavier fresh $(v \cdot, q-11, q \mathrm{~g})$ and dry $(17, r-20.2 \mathrm{~g})$ weights/ plant in the $1^{\text {st }}$ and $2^{\text {nd }}$ season, respectively when compared with two the other levels of fertilizers and control. On the other hand, the lowest recorded of the previous characters achieved from zero chemical fertilization level (control).

Table 2: Effect of chemical fertilizers levels of $N, P, K$ and microbial inoculations on plant height (cm)/ plant, number of branches)/ plant, number of leaves/ plant, fresh and dry weights/ plant of cowpea plants during the two summer seasons of 2009 and 2010.

\begin{tabular}{|c|c|c|c|c|c|c|c|c|c|c|}
\hline \multirow{2}{*}{\begin{tabular}{|c|} 
Characters \\
Treatments \\
$\begin{array}{c}\mathbf{N}, \mathbf{P} \text { and } \mathrm{K} \\
\text { levels }\end{array}$ \\
\end{tabular}} & \multicolumn{2}{|c|}{$\begin{array}{l}\text { Plant height } \\
(\mathrm{cm}) / \text { plant }\end{array}$} & \multicolumn{2}{|c|}{$\begin{array}{c}\text { Number of } \\
\text { branches/ plant }\end{array}$} & \multicolumn{2}{|c|}{$\begin{array}{c}\text { Number of } \\
\text { leaves/ plant }\end{array}$} & \multicolumn{2}{|c|}{$\begin{array}{l}\text { Fresh weight } \\
\text { (g)/ plant }\end{array}$} & \multicolumn{2}{|c|}{$\begin{array}{l}\text { Dry weight } \\
\text { (g)/ plant }\end{array}$} \\
\hline & 2009 & 2010 & 2009 & 2010 & 2009 & 2010 & 2009 & 2010 & 2009 & 2010 \\
\hline $0 \%$ & 27.3 & 31.2 & 3.3 & 3.7 & 15.9 & 17.5 & 45.6 & 53.6 & 9.74 & 12.32 \\
\hline $0 . \%$ & rT, & $r 4,9$ & 3.7 & 4.0 & 22.5 & 25.3 & 47.9 & 59.2 & 10.30 & 13.46 \\
\hline $\mathrm{V} \odot \%$ & $r q, \varepsilon$ & $\varepsilon \varepsilon, \Lambda$ & $\varepsilon, Y$ & $\varepsilon, 9$ & ro,r & $r \wedge, q$ & $v \cdot, 9$ & 11,9 & $17, \wedge \mathrm{V}$ & $r \cdot, 7 T$ \\
\hline $1 \ldots \%$ & $M 7,0$ & $\varepsilon 1, Y$ & $r, V$ & $\varepsilon, 0$ & $T r, 1$ & ro, & $77, Y$ & $V 7,0$ & 14,91 & $\mid v, 01$ \\
\hline L S D at $5 \%$ & 2.47 & 2.03 & 0.74 & 0.91 & 1.50 & 1.81 & 2.19 & 2.76 & 0.98 & 1.03 \\
\hline $\begin{array}{c}\text { Microbial } \\
\text { inoculations }\end{array}$ & 2009 & 2010 & 2009 & 2010 & 2009 & 2010 & 2009 & 2010 & 2009 & 2010 \\
\hline BO & 32.3 & $r v, 1$ & $r, Y$ & $r, \Lambda$ & 19,1 & 22.8 & $0 \leqslant, Y$ & $7 \leqslant, 0$ & 11.85 & 10,11 \\
\hline B1 & $r 0, \varepsilon$ & $r 9,7$ & $\varepsilon$, & $\varepsilon, V$ & $r 1, V$ & $r_{0, \Sigma}$ & 09,1 & 70.8 & 12.94 & 16.56 \\
\hline B2 & Tr, & $r v, r$ & $r, v$ & $\varepsilon, Y$ & $r \cdot, \Lambda$ & $T r, T$ & 07,1 & 77,9 & $M, \varepsilon \varepsilon$ & $10, \leqslant 0$ \\
\hline B3 & rT,O & $r 4, r$ & $r, \tau$ & $r, \Lambda$ & $r \cdot, r$ & $r Y, \Lambda$ & 00,7 & $7 \varepsilon, 9$ & $\mid r, 01$ & $10, \leqslant 9$ \\
\hline B4 & $r q, r$ & $\sum Y, 0$ & $\varepsilon, r$ & $\varepsilon, \Lambda$ & $r \varepsilon, V$ & $r V, \varepsilon$ & $\pi, T$ & 81,9 & 14,89 & $I V, Y T$ \\
\hline L S D at $5 \%$ & 1.78 & 1.65 & 0.47 & 0.53 & 1.17 & 1.77 & 2.78 & 3.14 & 0.63 & 0.69 \\
\hline
\end{tabular}

B0= without microbial inoculation- B1= Azospirillum sp. and Trichoderma sp. B2= Bacillus megaterium. B3= Pseudomonas fluorescens. B4= mixtures of all previous.

Concerning the effect of chemical fertilizers of nitrogen, phosphorus and potassium application on cowpea plants, the results are going in the same line with those obtained by many authors as: Ferreira (2004) postulated that increments of phosphorus allowed the growth of roots which resulted in increased number of leave. Singh et al. (2006) indicate that cowpea response (cv. Narendra Lobia-2) to $P$ fertilizer $(0,25,50$ or $75 \mathrm{Kg} / \mathrm{ha}$.) at $P 50 \mathrm{Kg} / \mathrm{ha}$. gave the highest number of leaves per plant, vine length, number of nodules per plant. El-Waraky and Kasem (2007) explained that increasing applied $\mathrm{N}$ rate up to $40 \mathrm{Kg} \mathrm{N} / \mathrm{fed}$. led to significant increases in plant height, number of leaves and branches of cowpea seeds cv. Kafer El-Sheikh - 1. Moreover, 
Farahvash et al. (2010) suggested the adding nitrogen chemical fertilizers (without urea, 50, 100 and $150 \mathrm{Kg} / \mathrm{ha}$. urea). Nitrogen had significant effect only on leaf number per plant by application of 50 and $150 \mathrm{Kg} / \mathrm{ha}$. urea of cowpea. Azarpour et al. (2011) mentioned that the maximum plant height of cowpea was recorded from usage of $45 \mathrm{Kg} / \mathrm{ha}$. pure nitrogen from urea fertilizer.

1-b- Effect of microbial inoculations (biofertilizer):

As shown in the same Table 2, the microbial inoculations of cowpea seed with the mixtures of all microbial inoculations of Azospirillum sp. and Trichoderma sp. for nitrogen, Bacillus megaterium for phosphorus and Pseudomonas fluorescens for potassium brought about significant increased of vegetative growth characters i.e. plant height, number of branches and leaves and both fresh and dry weights/ plant, followed by individual inoculation with microbial of Azospirillum sp. and Trichoderma sp. for nitrogen in the $1^{\text {st }}$ and $2^{\text {nd }}$ season, respectively. On the other hand, insignificant differences produced with microbial inoculations of each Bacillus megaterium and Pseudomonas fluorescens when compared with the control uninoculations plants. These results are come to the same conclusion by Yousry et al. (1987) who decided that inoculation of pea (Pisum sativum) plants with Bacillus megatherium increased plant dry matter by $10.9 \%$, while the combined application of $B$. megatherium and P-fertilizer increased dry matter by $19.7 \%$. Singh et al. (2006) studied microbial inoculation Rhizobium inoculated to seeds at $0.5 \mathrm{Kg} / \mathrm{ha}$, VAM (vesicular arbuscular mycorrhiza) inoculated to soil at $5 \mathrm{Kg} / \mathrm{ha}$, or Rhizobium + VAM), and found That the inoculation of Rhizobium + VAM resulted in the highest number of leaves, vine length and number of nodules per plant of cowpea cv. Narendra Lobia-2. El-Waraky and Kasem (2007) pointed out that inoculation of cowpea seeds cv. Kafer El-Sheikh - 1 with biofertilizer (Halex-2: a biofertilizer containing a mixture of non symbiotic $\mathrm{N}_{2}$-fixing bacteria of the genera Azospirillum, Azotobacter and Klebsiclla) significantly increased in plant height, number of leaves and branches. Farahvash et al. (2010) referred that biofertilizers of cowpea (without biofertilizers, Azotobacter, nitroxine and nitroxine + Azotobacter) caused significant effect on leaf number and plant height.

1-c- Effect of interactions between chemical fertilizers levels and microbial inoculations:

There were significant interactions between the chemical fertilizers levels and microbial inoculations for plant height, number of branches and leaves as well as both fresh and dry weights/plant Table 3 . The best characters obtained with adding the fertilization dose of $75 \%$ the recommended of $\mathrm{N}, \mathrm{P}, \mathrm{K}$ and the mixtures of all microbial inoculations followed by individual microbial inoculation with Azospirillum sp. Trichoderma $\mathrm{sp}$. for nitrogen when compared to the control untreated plants. Similar results were also reported by Kahlon and Sharanappa (2006) were found that application of $50 \mathrm{Kg} \mathrm{P}_{2} \mathrm{O}_{5} / \mathrm{ha}$. along with a phosphorus-solubilizing bacterium (PSB; Bacillus megaterium var. phosphaticum) and vesicular arbuscular mycorrhiza (VAM; Glomus mosseae) resulted in higher dry matter accumulation in leaves, stem and total dry matter accumulation. Higher number of nodules, dry matter of nodules and affectivity of nodules noticed 
with $50 \mathrm{Kg} \mathrm{P}_{2} \mathrm{O}_{5}$ /ha. along with PSB and VAM. El-Waraky and Kasem (2007) mentioned that applied $\mathrm{N}$ at any rate and inoculation of cowpea seeds $\mathrm{cV}$. Kafer El-Sheikh - 1 with biofertilizer (Halex-2) increased plant height, number of leaves and branches. Also, the combination of $40 \mathrm{Kg} \mathrm{N} / \mathrm{fed}$. Plus (Halex2) was the best treatment for improving most vegetative growth characters.

Table 3: Effect of the interaction between chemical fertilizers levels of $\mathrm{N}$, $\mathrm{P}, \mathrm{K}$ and microbial inoculations on plant height $(\mathrm{cm})$, number of branches, number of leaves/ plant, fresh and dry weights/ plant of cowpea plants during the two summer seasons of 2009 and 2010.

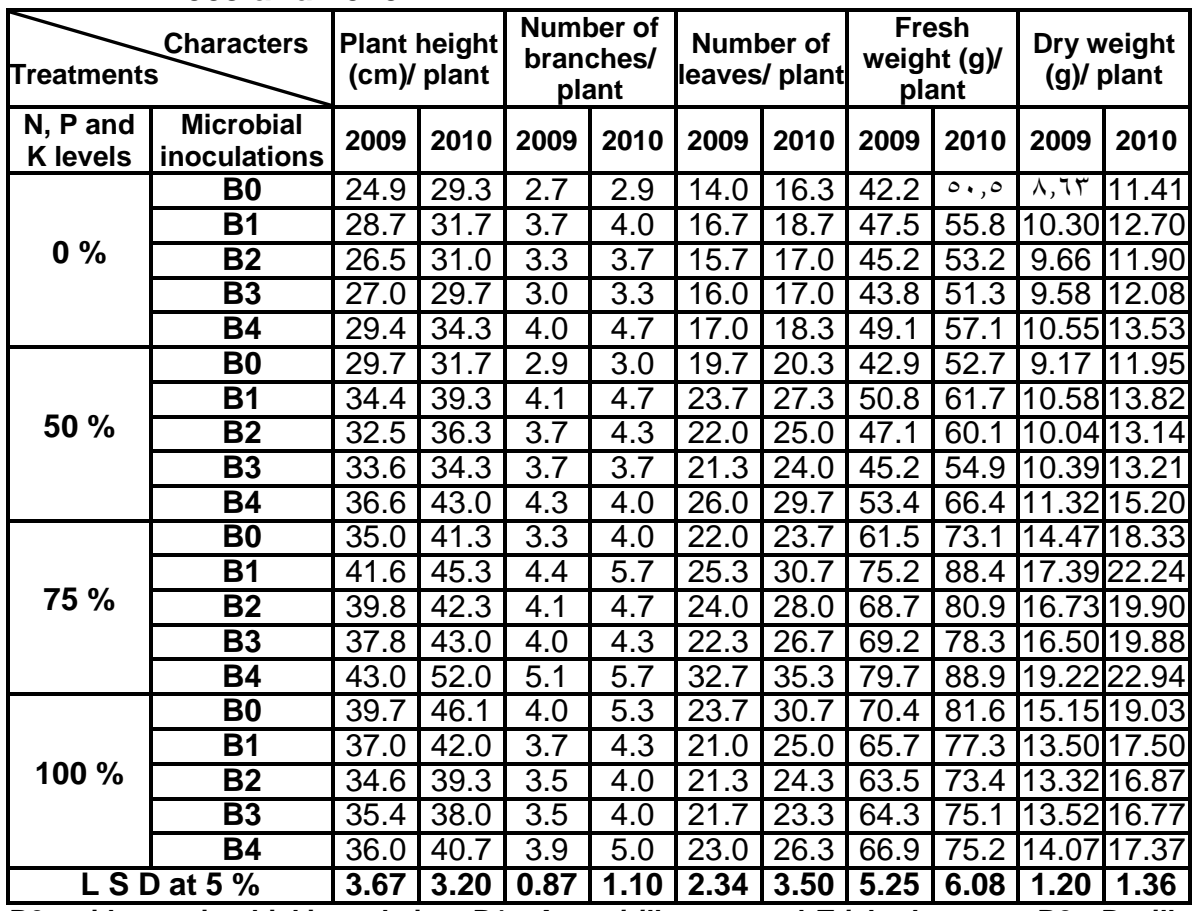

$\mathrm{B0}=$ without microbial inoculation- B1= Azospirillum sp. and Trichoderma sp. B2= Bacillus megaterium. B3= Pseudomonas fluorescens. B4= mixtures of all previous.

Farahvash et al. (2010) found significant effect of interactions between the chemical nitrogen and biofertilizers on leaf dry weight of cowpea. The tallest plants were obtained from urea and nitroxine, while the shortest plants belonged to Azotobacter and Azotobacter + nitroxine. The highest leaf dry weight was observed for $100 \mathrm{Kg} / \mathrm{ha}$. chemical $\mathrm{N}+$ Azotobacter and 150 $\mathrm{Kg} / \mathrm{ha} .+$ nitroxine, while the lowest value belonged to $150 \mathrm{Kg} / \mathrm{ha}$. urea + nitroxine + Azotobacter.

2- Total dry seed yield (ton/fed.) and pod characters of cowpea:

2-a- Effect of chemical fertilizers levels ( $N, P$ and $K$ ):

Data presented in Table 4 revealed that the $3^{\text {rd }}$ fertilization level $(75 \%$ recommended dose) i.e. $46.4 \mathrm{~N}, 23.3 \mathrm{P}_{2} \mathrm{O}_{5}$ and $28.1 \mathrm{~K}_{2} \mathrm{O}$ pure $\mathrm{Kg} /$ fed. produced significantly the heaviest total dry seed yield (ton/ fed.) of cowpea 
pod, length $(\mathrm{cm})$, number of seeds/ pod and 100 seed weight $(\mathrm{g})$ as compared to control treatment (zero level fertilization treatment) and the other two fertilization levels. On the other hand, pod diameter $(\mathrm{cm})$ had insignificant effect when compared to the control treatment. These results also are in agreement with Tyiem and Chieng (2003), Mazaheri and Hoseini (2003) on cowpea, Anuja et al. (2006) suggested that different levels of phosphorus and potassium (50, 60 and $70 \mathrm{Kg} / \mathrm{ha}$.) supplied with a constant rate of $\mathrm{N}(20$ $\mathrm{Kg} / \mathrm{ha}$.). Maximum yield was obtained under $\mathrm{P}$ at $70 \mathrm{Kg} / \mathrm{ha}$. + $\mathrm{K}$ at $70 \mathrm{Kg} / \mathrm{ha}$. of cowpea plant.

Table 4: Effect of chemical fertilizers levels of N, P, K and microbial inoculations on pod length $(\mathrm{cm})$, pod diameter $(\mathrm{cm})$, number of seeds/ pod, 100 seed weight (g) and total dry seed yield (ton/ fed.) of cowpea plants during the two summer seasons of 2009 and 2010.

\begin{tabular}{|c|c|c|c|c|c|c|c|c|c|c|}
\hline \multirow{2}{*}{\begin{tabular}{|c|} 
Characters \\
$\begin{array}{c}\text { N, P and } \mathrm{K} \\
\text { levels }\end{array}$ \\
\end{tabular}} & \multicolumn{2}{|c|}{$\begin{array}{l}\text { Pod length } \\
\text { (cm) }\end{array}$} & \multicolumn{2}{|c|}{$\begin{array}{c}\text { Pod diameter } \\
(\mathrm{cm})\end{array}$} & \multicolumn{2}{|c|}{$\begin{array}{l}\text { No. of seeds/ } \\
\text { pod }\end{array}$} & \multicolumn{2}{|c|}{$\begin{array}{l}100 \text { seed } \\
\text { weight }(g)\end{array}$} & \multicolumn{2}{|c|}{$\begin{array}{c}\text { Total dry seed } \\
\text { yield } \\
\text { (Ton/fed.) }\end{array}$} \\
\hline & 2009 & 2010 & 2009 & 2010 & 2009 & 2010 & 2009 & 2010 & 2009 & 2010 \\
\hline$\%$ & 11.30 & 12.06 & 0.69 & 0.74 & 7.82 & 8.29 & 11.28 & 11.09 & 0.500 & 0.531 \\
\hline $0 . \%$ & 11.77 & 12.60 & 0.73 & 0.77 & 8.20 & 8.69 & 11.76 & 12.53 & 0.587 & 0.647 \\
\hline $\mathrm{V} \bullet \%$ & $1 Y, 9$. & 15,90 & $\cdot, 179$ & $\cdot, \wedge 1$ & $9,7 \varepsilon$ & $1 \cdot, M V$ & $1 \pi, 0$. & $1 \leq, 1$. & $\cdot, 70 \leqslant$ & $\cdot, \mathrm{V} \backslash \mathrm{V}$ \\
\hline $1 \ldots \%$ & $M, Y \leq$ & $T r, 9 T$ & $\cdot, 1,0$ & $\cdot, \mathrm{VA}$ & $\lambda, 0 \wedge$ & $9, \cdot 1$ & $T Y, Y Y$ & $T r, \wedge T$ & $\cdot, 7 Y \leq$ & $\cdot, T V T$ \\
\hline L S D at $5 \%$ & 0.36 & 0.32 & N.S. & N.S. & 0.25 & 0.27 & 0.41 & 0.38 & 0.045 & 0.039 \\
\hline $\begin{array}{c}\text { Microbial } \\
\text { inoculations }\end{array}$ & 2009 & 2010 & 2009 & 2010 & 2009 & 2010 & 2009 & 2010 & 2009 & 2010 \\
\hline BO & 11.67 & $1 T, 7$. & $\cdot, \mathrm{VT}$ & $\cdot, \sqrt{ } \times 7$ & $\Lambda, \cdot r$ & $\Lambda, \vee \leqslant$ & 11,10 & $1, T, 0$. & $\cdot, 079$ & $\cdot, 717$ \\
\hline B1 & 11,199 & $|r, T|$ & $\cdot, V T$ & $\cdot, \sqrt{ } / 7$ & $\Lambda, 1 T$ & $1, \vee v 0$ & $11, \wedge \wedge$ & Ir,Or & $\cdot, 0 V T$ & $\cdot, 719$ \\
\hline B2 & $M, \cdot \Lambda$ & 11,90 & $\cdot, V \leq$ & $\cdot, \mathrm{VA}$ & 1,70 & 9,17 & $T, Y$. & $I T, V$. &., 09. & $\cdot, 7 \leq \leq$ \\
\hline B3 & $|r, r|$ & $1 T, \cdot 7$ & $\cdot, 1 \times 0$ & $\cdot, 1 \times 9$ & $\wedge, \wedge 0$ & $9, \leqslant Y$ & Ir,Or & $I T, Y$. & $\cdot, 7 \mid r$ &., 709 \\
\hline B4 & $|r, \varepsilon|$ & $|r, Y|$ & $\cdot, \sqrt{ } \times 7$ & $\cdot, \mathrm{VA}$ & 9,10 & $9, r v$ & $|r, T|$ & 14,40 & $\cdot, 71 Y$ & $\cdot, T V T$ \\
\hline L S D at $5 \%$ & 0.33 & 0.29 & N.S. & N.S. & 0.17 & 0.21 & 0.27 & 0.24 & 0.032 & 0.026 \\
\hline
\end{tabular}
megaterium. B3= Pseudomonas fluorescens. B4= mixtures of all previous.

Singh et al. (2006) indicate that cowpea response (cv. Narendra Lobia-2) to $P$ fertilizer $(0,25,50$ or $75 \mathrm{Kg} / \mathrm{ha}$.) at $P 50 \mathrm{Kg} / \mathrm{ha}$. gave the highest number of pods per plant, pod length, pod diameter, pod weight and pod yield. El-Waraky and Kasem (2007) defined that increasing applied $\mathrm{N}$ rate with 30 and $40 \mathrm{Kg} \mathrm{N}$ /fed. significantly increased seed yield/ fed., number of pods /plant, number of seeds per pod and weight of 100-seeds of cowpea. (Abayomi et al., 2008) concluded that nitrogen fertilizer had a positive effect on yield and yield components of cowpea. Farahvash et al. (2010) decided that the highest number of pods per plant was obtained by adding $50 \mathrm{~kg} / \mathrm{ha}$. urea to cowpea plants. Uarrota (2010) postulated that increasing phosphorus levels (as form of superphosphate) from 20 to $40 \mathrm{Kg} / \mathrm{ha}$. positively increase yield of grain and number of pods per plant of cowpea cv. IT at high level of $40 \mathrm{Kg} / \mathrm{ha}$. compared to the control (zero level Kg/ha. phosphorus).

Moreover, Azarpour et al. (2011) assumed that the maximum seed yield, number of pod per plant, number of seeds per pod, pod length, seed 
length and seed width were recorded from use of $45 \mathrm{Kg} / \mathrm{ha}$. pure nitrogen from source of urea of cowpea.

\section{2-b- Effect of microbial inoculations (biofertilizer):}

It is obvious from the data in the same Table that, the maximum total dry seed yield (ton/ fed.) of cowpea was noticed significant increased from seed inoculated with either mixture (B4) of microbial inoculation i.e. Azospirillum $\mathrm{sp}$. and Trichoderma sp. (B1), Bacillus megaterium (B2) and Pseudomonas fluorescens (B3) or individually with Pseudomonas fluorescens in the two seasons and Bacillus megaterium in the $2^{\text {nd }}$ season only as well as pod characters. Individual seed microbial inoculated of Bacillus megaterium obtained non-significant effect in the 100 seed weight $(\mathrm{g})$ in the $2^{\text {nd }}$ season only. Pod diameter $(\mathrm{cm})$ had non-significant effect in the two seasons. On the other hand, seed inoculation with Azospirillum sp. and Trichoderma sp. tendency to increase yield and pod characters but this increment had nonsignificant different when compared to the control (un-inoculation seeds). The results are in contradiction with those reported by Singh et al. (2006) studied that response of cowpea cv. Narendra Lobia-2 to microbial inoculation (Bradyrhizobium inoculated to seeds at $0.5 \mathrm{Kg} / \mathrm{ha}$., VAM [vesicular arbuscular mycorrhiza] inoculated to soil at $5 \mathrm{Kg} / \mathrm{ha}$., or Rhizobium + VAM). The inoculation of Bradyrhizobium + VAM number of pods per plant, pod length, pod diameter, pod weight pod yield. El-Waraky and Kasem (2007) reported that inoculation of cowpea seeds cv. Kafer El-Sheikh - 1 with biofertilizer (Halex-2) led to significant increases in total seed yield/ fed., number of pods /plant and weight of 100-seeds of cowpea. Farahvash et al. (2010) stated that significant effect of biofertilizer (without biofertilizers, Azotobacter, nitroxine and nitroxine + Azotobacter) on seed yield of cowpea. Musa et al. (2011) postulated that inoculation seed of cowpea with Bradyrhizobium strain significantly increased the seed yield.

2-c- Effect of interactions between chemical fertilizers levels and microbial inoculations:

Results of the interaction effect between chemical fertilizers and microbial inoculations on total dry seed yield and pod characters of cowpea presented in the Table 5 were significant. Trait of pod diameter $(\mathrm{cm})$ exhibited non-significant effect. The highest total dry seed yield (ton/ fed.) of cowpea was recorded from use the mixtures of all microbial inoculations and application of $75 \%$ from the recommended dose of chemical fertilization level which was 0.691 and 0.783 ton/ fed. of total dry seed in both $1^{\text {st }}$ and $2^{\text {nd }}$ season, respectively. These results are consistent with those of El-Waraky and Kasem (2007) stated that combined with (Halex-2) biofertilizer with $\mathrm{N}$ fertilizer at the rate of $30 \mathrm{Kg} \mathrm{N} /$ fed. gave a high seed yield, number of pods/plant, number of seeds/ pod and weight of 100- seeds of cowpea. Singh et al. (2007) proved Rhizobium inoculation, $30 \mathrm{Kg} \mathrm{N}$ and $60 \mathrm{Kg} \mathrm{P} \mathrm{O}_{5} / \mathrm{ha}$. produced significantly higher number of pods/plant, length/pod, seed index, seed and straw yield of cowpea cv. Narendra Lobia over control. Farahvash et al. (2010) declared that significant effect of interactions between the chemical nitrogen and biofertilizers. Maximum number of pods per plant belonged to 50 inoculation seeds of cowpea with Bradyrhizobium strain plus 
$\mathrm{N}$ and Bradyrhizobium plus $\mathrm{P}$ fertilizers, significantly increased seeds yield of cowpea. Musa et al. (2011) suggested that inoculation seeds of cowpea with Bradyrhizobium strain plus $\mathrm{N}$ and Bradyrhizobium plus $\mathrm{P}$ fertilizers. significantly increased the seeds yield of cowpea.

Table 5: Effect of the interaction between chemical fertilizers levels of $\mathrm{N}$, $P, K$ and microbial inoculations on pod length $(\mathrm{cm})$, pod diameter $(\mathrm{cm})$, number of seeds/ pod, 100 seed weight $(\mathrm{g})$ and total dry seed yield (ton/ fed.) of cowpea plants during the two summer seasons of 2009 and 2010.

\begin{tabular}{|c|c|c|c|c|c|c|c|c|c|c|c|}
\hline \multicolumn{2}{|c|}{ Characters } & \multicolumn{2}{|c|}{$\begin{array}{l}\text { Pod length } \\
\text { (cm) }\end{array}$} & \multicolumn{2}{|c|}{$\begin{array}{c}\text { Pod diameter } \\
\text { (cm) }\end{array}$} & \multicolumn{2}{|c|}{$\begin{array}{c}\text { No. of } \\
\text { seeds/ pod }\end{array}$} & \multicolumn{2}{|c|}{$\begin{array}{l}100 \text { seed } \\
\text { weight }(g)\end{array}$} & \multicolumn{2}{|c|}{$\begin{array}{l}\text { Total dry } \\
\text { seed yield } \\
\text { (Ton/ fed.) }\end{array}$} \\
\hline $\begin{array}{l}\mathrm{N}, \mathrm{P} \text { and } \\
\mathrm{K} \text { levels }\end{array}$ & \begin{tabular}{|c|}
$\begin{array}{c}\text { Microbial } \\
\text { inoculations }\end{array}$ \\
\end{tabular} & 2009 & 2010 & 2009 & 2010 & 2009 & 2010 & 2009 & 2010 & 2009 & 2010 \\
\hline \multirow{5}{*}{$0 \%$} & B0 & 10.92 & 11.66 & 0.67 & 0.71 & 7.4 & 8.0 & 10.8 & 11.5 & \begin{tabular}{|l|l|}
0.471 \\
\end{tabular} & 0.591 \\
\hline & B1 & 11.11 & 11.91 & 0.70 & 0.73 & 7.6 & 8.0 & 11.0 & 11.7 & 0.480 & 0.527 \\
\hline & B2 & 11.49 & 12.15 & 0.69 & 0.73 & 7.9 & 8.4 & 11.4 & 11.7 & 0.507 & 0.533 \\
\hline & B3 & 11.38 & 12.22 & 0.68 & 0.75 & 8.0 & 8.5 & 11.7 & 12.2 & 0.523 & 0.537 \\
\hline & B4 & 11.61 & 12.35 & 0.71 & 0.77 & 8.2 & 8.6 & 11.5 & 12.4 & 0.520 & 0.540 \\
\hline \multirow{5}{*}{$50 \%$} & B0 & 11.33 & 12.03 & 0.69 & 0.73 & 7.6 & 8.2 & 11.0 & 11.9 & 0.550 & 0.585 \\
\hline & B1 & 11.55 & 12.44 & 0.72 & 0.76 & 7.9 & 8.4 & 11.5 & 12.3 & 0.566 & 0.626 \\
\hline & B2 & 11.75 & 12.67 & 0.73 & 0.77 & 8.2 & 8.7 & 11.8 & 12.6 & 0.584 & 0.655 \\
\hline & B3 & 11.93 & 12.98 & 0.75 & 0.80 & 8.5 & 9.1 & 12.1 & 12.9 & 0.616 & 0.672 \\
\hline & B4 & 12.28 & 12.88 & 0.74 & 0.79 & 8.8 & 9.0 & 12.4 & 13.1 & 0.618 & 0.695 \\
\hline \multirow{5}{*}{$75 \%$} & B0 & 11.79 & 13.20 & 0.75 & 0.77 & 8.1 & 9.1 & 12.3 & 13.1 & 0.590 & 0.637 \\
\hline & B1 & 12.63 & 13.85 & 0.77 & 0.79 & 8.9 & 10.1 & 13.1 & 13.7 & \begin{tabular}{|l|l|}
0.647 \\
\end{tabular} & 0.688 \\
\hline & B2 & 13.07 & 14.07 & 0.80 & 0.83 & 10.1 & 10.7 & 13.6 & 13.9 & 0.659 & 0.732 \\
\hline & B3 & 13.53 & 14.14 & 0.80 & 0.85 & 10.4 & 10.8 & 14.0 & 14.7 & 0.682 & 0.744 \\
\hline & B4 & 13.47 & 14.48 & 0.82 & 0.82 & 10.7 & 11.1 & 14.5 & 15.1 & 0.691 & 0.783 \\
\hline \multirow{5}{*}{$100 \%$} & B0 & 12.65 & 13.50 & 0.79 & 0.82 & 9.0 & 9.6 & 12.9 & 13.5 & 0.665 & 0.722 \\
\hline & B1 & 11.85 & 12.25 & 0.73 & 0.75 & 8.1 & 8.4 & 11.9 & 12.4 & 0.600 & 0.633 \\
\hline & B2 & 12.02 & 12.89 & 0.74 & 0.78 & 8.4 & 8.9 & 12.0 & 12.6 & 0.610 & 0.655 \\
\hline & B3 & 12.41 & 12.91 & 0.75 & 0.78 & 8.5 & 9.3 & 12.3 & 13.0 & 0.630 & 0.681 \\
\hline & B4 & 12.27 & 13.11 & 0.76 & 0.77 & 8.9 & 8.8 & 12.0 & 12.8 & 0.617 & 0.675 \\
\hline \multicolumn{2}{|c|}{ LSD at $5 \%$} & 0.61 & 0.45 & N.S. & N.S. & 0.33 & 0.42 & 0.51 & 0.47 & 0.065 & 0.053 \\
\hline
\end{tabular}

B0= without microbial inoculation- B1= Azospirillum sp. and Trichoderma sp. B2= Bacillus megaterium. B3= Pseudomonas fluorescens. B4= mixtures of all previous.

3- Chemical composition in leaves and protein content (\%) in seeds of cowpea:

3-a- Effect of chemical fertilizers levels ( $N, P$ and $K$ ):

Data illustrated in Table 6 clearly revealed that there were significant increases in the chemical composition in leaves and protein content $(\%)$ in seeds of cowpea; due to add the $3^{\text {rd }}$ of chemical fertilization level $(75 \%$ of $\mathrm{N}$, $\mathrm{P}$ and $\mathrm{K}$ ) which were superior in those respects as a compared with the rest of the other studied levels. These results are in line with those reported by ElWaraky and Kasem (2007) who stated that applied N rate with 30 and $40 \mathrm{Kg}$ $\mathrm{N}$ /fed. significantly increased seed crude protein content of cowpea. Because nitrogen is a constituent of protein, it increases with $\mathrm{N}$ content in tissue (Marschner, 1995). Anuja et al. (2006) demonstrated that $\mathrm{P}$ and $\mathrm{K}$ at 
50,60 and $70 \mathrm{Kg} / \mathrm{ha}$. fertilizers were supplied with a constant rate of $\mathrm{N}(20$ $\mathrm{Kg} / \mathrm{ha}$.) of cowpea cv. TUX 944. and found that crude protein content increased with increasing levels of $P$ and $K$. at $P: K$ at $70: 70 \mathrm{Kg} / \mathrm{ha}$. Farahvash et al. (2010) commented that nitrogen had significant effect on percentage of protein from 100 and $150 \mathrm{Kg} / \mathrm{ha}$. urea in seeds of cowpea.

Table 6: Effect of chemical fertilizers levels of $\mathrm{N}, \mathrm{P} K$ and microbial inoculations on nitrogen (\%), phosphorus (\%), potassium (\%) in leaves and protein (\%) in seeds content of cowpea plants during the two summer seasons of 2009 and 2010.

\begin{tabular}{|c|c|c|c|c|c|c|c|c|}
\hline \multirow{2}{*}{$\begin{array}{l}\text { Characters } \\
\text { Treatments } \\
\begin{array}{c}\text { N, P and } \mathrm{K} \\
\text { levels }\end{array}\end{array}$} & \multicolumn{2}{|c|}{$\begin{array}{l}\text { Nitrogen in } \\
\text { leaves (\%) }\end{array}$} & \multicolumn{2}{|c|}{$\begin{array}{c}\text { Phosphorus in } \\
\text { leaves (\%) }\end{array}$} & \multicolumn{2}{|c|}{$\begin{array}{c}\text { Potassium in } \\
\text { leaves (\%) }\end{array}$} & \multicolumn{2}{|c|}{$\begin{array}{l}\text { Protein in } \\
\text { seeds (\%) }\end{array}$} \\
\hline & 2009 & 2010 & 2009 & 2010 & 2009 & 2010 & 2009 & 2010 \\
\hline$\%$ & 2.42 & 2.56 & 0.159 & 0.198 & 1.585 & 1.794 & 17.85 & 19.53 \\
\hline$\%$ & $r, 70$ & $r, \wedge 0$ & $\cdot, 110$ & • & $1, V 1 \leq$ & $r, 11 r$ & $19, \mathrm{rV}$ & $r,, 1 \leq$ \\
\hline$\% \vee 0$ & $r, 9 \wedge$ & $r, r$. & $\cdot, Y O Y$ & $\cdot, \mu \cdot \Lambda$ & $r, Y q \wedge$ & $r, \Sigma) r$ & r), rq & $r 1,9 r$ \\
\hline$\% 1 \ldots$ & $r, 79$ & $r, \cdot T$ & $\cdot, r \cdot \Lambda$ & $\cdot, Y \wedge Y$ & $r, 109$ & $r, 107$ & $r \cdot, \cdot 9$ & rI, rr \\
\hline L S D at $5 \%$ & 0.36 & 0.30 & 0.075 & 0.057 & 0.063 & 0.075 & 0.93 & 0.87 \\
\hline $\begin{array}{c}\text { Microbial } \\
\text { inoculations }\end{array}$ & 2009 & 2010 & 2009 & 2010 & 2009 & 2010 & 2009 & 2010 \\
\hline $\mathrm{BO}$ & 2.53 & r, Vo & $\cdot, 1 \wedge \wedge$ & $\cdot, r \leq$. & 1.907 & $r, \cdot \varepsilon \varepsilon$ & 19.30 & $r_{\cdot}, r_{.}$ \\
\hline B1 & $r, \wedge V$ & $r, I V$ & $\cdot, 1 \wedge 9$ & $\cdot, r \leqslant 1$ & 1,9rr & $r, .70$ & $r \cdot 10$ & $r, r_{\Lambda}$ \\
\hline B2 & $r, T \varepsilon$ & $r, \wedge V$ & $\cdot, Y \backslash V$ & $\cdot, Y 70$ & 1,9rr & $r, \cdot \lambda r$ & 19,77 & $r \cdot, T r$ \\
\hline B3 & $r, 7 T$ & $r, v q$ & $\cdot, Y \cdot 1$ & $\cdot, r \circ \Lambda$ & 1,910 & $r, Y T$. & $19,0$. & $r \cdot, \leqslant \Lambda$ \\
\hline B4 & $r, V T$ & $r, \cdot 1$ & $\cdot, r \cdot q$ & $\cdot, r 79$ & $1,9 \leq 1$ & $r, 1 \leq r$ & 19,81 & $r \cdot, 9 V$ \\
\hline LSD at $5 \%$ & 0.18 & 0.14 & 0.027 & 0.021 & 0.046 & 0.070 & 0.56 & 0.48 \\
\hline
\end{tabular}

B0= without microbial inoculation- B1= Azospirillum sp. and Trichoderma sp. B2= Bacillus megaterium. B3= Pseudomonas fluorescens. B4= mixtures of all previous.

\section{3-b- Effect of microbial inoculations (biofertilizer):}

Data presented in Table 6 show that treating seeds of cowpea with individual of the each of microbial inoculation and the mixtures of all microbial inoculations obtained markedly enhanced effect on nitrogen (\%), phosphorus (\%) and potassium content (\%) in leaves. Individual microbial inoculation of Azospirillum sp. and Trichoderma sp. followed with the mixtures of all microbial inoculations gave the highest protein content (\%) in seeds. These results in agreement with those reported by Ramadan et al. (2002) they concluded that nitrogen uptake by cowpea plants were increased by $49.78 \%$. Inoculation by mycorrhiza or phosphate dissolving bacteria increased $\mathrm{P}$ supply which led to improve $\mathrm{P}$ uptake by cowpea plants for sandy soils. ElWaraky and Kasem (2007) proposed that inoculation of cowpea seeds with the biofertilizer (Halex-2) significantly increased seed crude protein content of cowpea. Shahaby (1997) generalized that nitrogen fixation bacteria increased total nitrogen content in the Nile valley and reclaimed soil. Phosphate solubilizing bacteria (Bacillus polymyxa and Pseudomonas fluorescens) release organic and inorganic acids which reduce soil $\mathrm{pH}$ leading to change of phosphorus and other nutrients to available forms ready for uptake by plants (Singh and Kapoor, 1999). 
3-c- Effect of interactions between chemical fertilizers levels and microbial inoculations and protein content (\%) in seeds:

The most favorable treatment of the interaction obtained with the application of $75 \%$ recommended fertilization and inoculation seeds of cowpea with the mixtures of all microbial inoculations (Table 7) helped in producing the most pronounced effects of nitrogen, phosphorus and potassium content (\%) in leaves. On the other hand, seed inoculations with Azospirillum sp. and Trichoderma sp. significantly increased nitrogen and protein content (\%) in leaves and seeds, respectively. when compared to the other inoculations and control untreated plants. Also, inoculation seeds of cowpea with the Bacillus megaterium and Pseudomonas fluorescens significant effect on phosphorus and potassium content (\%) in leaves, respectively compared to uninoculated seeds of cowpea.

Table 7: Effect of the interaction between chemical fertilizers levels of $N$, $P$ and $K$ and microbial inoculations on nitrogen (\%), phosphorus (\%), potassium (\%) in leaves and protein (\%) in seeds content of cowpea plants during the two summer seasons of 2009 and 2010.

\begin{tabular}{|c|c|c|c|c|c|c|c|c|c|}
\hline \multicolumn{2}{|c|}{ Treatments } & \multicolumn{2}{|c|}{$\begin{array}{l}\text { Nitrogen in } \\
\text { leaves (\%) }\end{array}$} & \multicolumn{2}{|c|}{$\begin{array}{l}\text { Phosphorus } \\
\text { in leaves (\%) }\end{array}$} & \multicolumn{2}{|c|}{$\begin{array}{l}\text { Potassium in } \\
\text { leaves (\%) }\end{array}$} & \multicolumn{2}{|c|}{$\begin{array}{l}\text { Protein in } \\
\text { seeds (\%) }\end{array}$} \\
\hline $\begin{array}{c}\mathrm{N}, \mathrm{P} \text { and } \mathrm{K} \\
\text { levels }\end{array}$ & $\begin{array}{c}\text { Microbial } \\
\text { inoculations }\end{array}$ & 2009 & 2010 & 2009 & 2010 & 2009 & 2010 & 2009 & 2010 \\
\hline \multirow{5}{*}{$0 \%$} & B0 & 2.13 & 2.35 & 0.144 & 0.186 & 1.571 & 1.7403 & 17.24 & 18.78 \\
\hline & B1 & 2.60 & 2.87 & 0.143 & 0.193 & 1.588 & 1.751 & 18.41 & 19.85 \\
\hline & B2 & 2.43 & 2.50 & 0.168 & 0.201 & 1.576 & 1.801 & 17.70 & 19.55 \\
\hline & B3 & 2.40 & 2.37 & 0.161 & 0.199 & 1.611 & 1.881 & 17.31 & 19.25 \\
\hline & B4 & 2.53 & 2.70 & 0.177 & 0.210 & 1.580 & 1.796 & 18.60 & 20.21 \\
\hline \multirow{5}{*}{$50 \%$} & B0 & 2.41 & 2.50 & 0.173 & 0.202 & 1.606 & 1.998 & 18.64 & 19.41 \\
\hline & B1 & 3.02 & 3.13 & 0.185 & 0.224 & 1.713 & 2.094 & 20.12 & 20.95 \\
\hline & B2 & 2.62 & 2.77 & 0.193 & 0.253 & 1.737 & 2.078 & 19.68 & 20.11 \\
\hline & B3 & 2.53 & 2.83 & 0.182 & 0.233 & 1.775 & 2.087 & 19.40 & 19.80 \\
\hline & B4 & 2.67 & 3.00 & 0.190 & 0.245 & 1.739 & 2.110 & 19.01 & 20.72 \\
\hline \multirow{5}{*}{$75 \%$} & B0 & 2.65 & 2.87 & 0.203 & 0.249 & 2.012 & 2.218 & 19.42 & 20.17 \\
\hline & B1 & 3.27 & 3.53 & 0.230 & 0.287 & 2.253 & 2.301 & 21.10 & 23.15 \\
\hline & B2 & 3.00 & 3.20 & 0.293 & 0.321 & 2.289 & 2.325 & 21.77 & 21.95 \\
\hline & B3 & 3.10 & 3.17 & 0.261 & 0.329 & 2.444 & 2.637 & 21.94 & 21.78 \\
\hline & B4 & 2.90 & 3.23 & 0.275 & 0.353 & 2.491 & 2.643 & 21.73 & 22.56 \\
\hline \multirow{5}{*}{$100 \%$} & B0 & 2.95 & 3.27 & 0.233 & 0.325 & 2.437 & 2.281 & 21.91 & 22.72 \\
\hline & B1 & 2.60 & 3.13 & 0.198 & 0.261 & 2.138 & 2.114 & 19.97 & 21.55 \\
\hline & B2 & 2.50 & 3.00 & 0.215 & 0.285 & 2.131 & 2.127 & 19.49 & 20.88 \\
\hline & B3 & 2.62 & 2.80 & 0.201 & 0.270 & 2.111 & 2.237 & 19.33 & 21.10 \\
\hline & B4 & 2.80 & 3.10 & 0.195 & 0.286 & 1.980 & 2.020 & 19.76 & 20.38 \\
\hline \multicolumn{2}{|c|}{ L S D at $5 \%$} & 0.32 & 0.28 & 0.060 & 0.053 & 0.091 & 0.139 & 1.12 & 0.95 \\
\hline
\end{tabular}
megaterium. B3= Pseudomonas fluorescens. B4= mixtures of all previous. 
These results are in general agreement with reported with El-Waraky and Kasem (2007) that combined with (Halex-2) biofertilizer and applied $\mathrm{N}$ rate up to $\mathrm{r} \cdot \mathrm{Kg} \mathrm{N} / \mathrm{fed}$. led to significant increase seed crude protein content of cowpea. Singh et al. (2007) proved that Rhizobium inoculation, $30 \mathrm{Kg} \mathrm{N}$ and $60 \mathrm{Kg} \mathrm{P} \mathrm{O}_{5} / \mathrm{ha}$., protein content of seed was influenced by Rhizobium, nitrogen and phosphorus of cowpea cv. Narendra Lobia. Abdel-Hady (2009) demonstrated that fertilizing cowpea cv. Kaha -1 with combination of FYM + Biofertilizer (Phosphorine + Rhizobacterien) + 1/2 NPK (recommended doses) produced the highest number of branches/plant, highest pod length, highest number of seeds /pod, highest pod filling and protein contents when compared to the control untreated plants. Farahvash et al. (2010) recorded that significant effect of interactions between the chemical nitrogen and biofertilizers. The highest percent of protein was obtained from 100 and 150 $\mathrm{Kg} / \mathrm{ha}$. chemical $\mathrm{N}$ without biofertilizer and the lowest from Azotobacter when no $\mathrm{N}$ chemical was used. The results indicated that biofertilizers didn't increase protein yield alone of cowpea and they should be applied along with chemical fertilizers.

\section{REFERENCES}

Abayomi, Y. A.; T. V. Ajibade; O. F. Samuel and B. F. Saadudeen 2008. Growth and yield responses of cowpea (Vigna unguiculata, L. Walp) genotypes to nitrogen fertilizer (N. P. K.) application in the Southern Guinea Savanna zone of Nigeria. Asian J. Plant Sci., 7 (2): 170 - 176.

Abdel-Hady, M. A. 2009. Effect of organic, inorganic and biofertilization on growth, flowering, yield and quality of cowpea crop (Vigna unguiculata, L.). Egypt. J. Appl. Sci., 24 (2B). $580-590$.

Abdel-Latif, M. R.; A. A. El-Bana and A. A. Galal 2001. Effect of biofertilizers Microbein and Phosphorine on Bacterial pod blight of guar and black cumin damping off root rot and with diseases. Proc. Of the fifth Arabian Horticulture Conference, Ismailia, Egypt, March 24-28.: 133 - 140.

Achilea, O.; D. Anac and P. Martin-Prevel 1999. Citrus and tomato quality is improved by optimized K nutrition. Improved Crop Quality by Nutrient Management, 19-22.

Adelusi, A. A. and J. D. Aileme 2006. Effects of light and nutrient stress on some growth parameters of cowpea (Vigna unguiculata, L. Walp). Res. J. Bot., 1: $95-103$.

Ankomah, A. B.; F. Zapata; G. Hardason and S. K. O. Danso 1995. Yield, nodulation and $\mathrm{n} 2$ fixation by cowpea cultivars at different phosphorus levels. Biology and Fertility of Soils 22: $10-15$.

Anuja, S.; K. Ilavarasi; S. Arumugam and A. Angayarkanni 2006. Effect of different levels of phosphorus and potassium on the yield and quality of vegetable cowpea. Plant Archives. 6: 1, 297-299.

Azarpour, E.; R. K. Danesh; S. Mohammadi; H. R. Bozorgi and M. Moraditochaee 2011. Effects of nitrogen fertilizer under foliar spraying of humic acid on yield and yield components of cowpea (Vigna unguiculata, L.). World Applied Sci., J. 13: 6, 1445-1449. 
Benton, J. J. 1998. Plant Nutrition Manual. London, New York, Washington, pp. 37-77.

Brown, J. G. and P. K. Jackson 1955. Anate on the potentiometric determination of chloride. Proc. Amer. Soc. Hort. Sci., 65:187-194.

Chiulele, R. M. 2003. Morphological and physiological responses of cowpea (Vigna unguiculata, L. Walp) cultivars to induced water stress and phosphorus nutrition. M. Sc. Thesis, Univ., South Africa. Stellenbosh.

Dorais, M; A. B. Papadoulos and A. Gosselin 2001. Greenhouse tomato fruit quality. Hort. Rev. 26: 262-319.

El-Bably, A. Z. and Y. B. El-Waraky 2006. Effect of irrigation schedualing using a pan evaporation and nitrogen fertilizer on cowpea productivity and water use efficiency. Alex. J. Agric., Res. 51 (3): 123 - 131.

El-Waraky, Y. B. and M. H. Kasem 2007. Effect of biofertilization and nitrogen levels on cowpea growth, production and seed quality. J. Agric. Res. Kafer El-Sheikh Univ., 33(2) 434 - 447.

Farahvash, F.; B. Mirshekari and Z. Niosha 2010. Effects of biofertilizers (Azotobacter and nitroxine) and different rates of chemical fertilizers on some attributes of cowpea (Vigna unguiculata, L. Walp). J. Food, Agric., \& Environment. 8: 2, part 2.

Ferreira, F. R. 2004. Effect of different levels of water deficit on yield of groundnut, cowpea and maize intercropping and pure culture. Undergrounduate. Thesis, College of Agric. and Forestry, Maputo.

Frankenberger, J. R. and M. Arshad 1995. Phytohormones in Soils. Microbial Production and Function. Marcel Dekker, New York.

Gomaa, A. O. and H. E. Abou-Aly 2001. Efficiency of bioferitlization in the presence of both inorganic and organic fertilizers on growth, yield and chemical constituents of anise plant (Pimpinella anisum L.). Proc. of the fifth Arabian Hort. Conf. Ismailia, Egypt, March. 24-28, pp. 73-80.

Kahlon, C. S. and R. K. Sharanappa 2006. Dry matter accumulation and nodulation as influenced by phosphorus bioinoculants, zinc and sulfur in cowpea (Vigna unguiculata, L. Walp). Environment and Ecology. 1, 120-124.

Kang, B. T. and D. Nangju 1983. Phosphorus Response of Cowpea (Vigna unguiculata, L. Walp). Tropical Grain Legume Bulletin 27: 11 - 16.

King, E. J. 1951. Micro-Analysis in Medical Biochemistry. $2^{\text {nd }}$ Ed., Churchil, Landon.

Marschner, H. 1995. Mineral Nutrition of Higher Plants. $2^{\text {nd }}$ Ed. Academic Press, London.

Mazaheri, D. and M. Hoseini 2003. Effect of nitrogen levels on yield and yield components of millet and cowpea. Pajuhesh and Sazandegi in Agron., Horti. 2: $60-67$.

Musa, E. M.; E. A. E. Elsheikh; I. A. M. Ahmed and E. E. Babiker 2011. Effect of intercropping, Bradyrhizobium inoculation and N, P fertilizers on yields, physical and chemical quality of cowpea seeds. Frontiers Agric., in China. 5: 4, 543-551.

Najafva, S. D.; A. Alemzadeh and N. D. Sedighie 2008. Effect of different levels of nitrogen fertilizer with two types of bio-fertilizers on growth and 
yield of two cultivars of tomato (Lycopersicone sculentum Mill). Asian J. Plant Sci. pp. 1-5.

Pergl, F. 1945. Quantitative Organic Micro Analysis. $4^{\text {th }}$, Ed. J. and Churchill Ltd. London.

Piper, G. S. 1947. Soil and Plant Analysis. Interscience Publishers, Inc. NY, $368 P$.

Raja, A. R.; K. H. Shah; M. Aslam and M. Y. Memon 2002. Response of phosphobacterial and mycorrhizal inoculation in wheat. Asian J. Plant Sci., 1 (4): 322-323.

Ramadan, H. M.; E. A. Koreish; H. M. Gaber and M. E. El-Fayoumy 2002. Assessment and comparison of bio and mineral fertilization on farm profitability in different newly-reclaimed soils. Alexandria J. Agric., Res. 47: 1, 133-146.

Rashid, A.; M. Aslam; A. Iqbal; A. R. Jami and M. R. Sajjid 1999. Use of Bacterial biofertilizers for improving crop productivity. Proc. Symp. Integrated Plant Nutr., Management Sci. 18: 69 -80.

Sample, E. C.; R. J. Soper and G. J. Racz 1980. Reactions of phosphorus fertilizers in soils. P. $263-310$ In: the Role of Phosphorus in Agriculture, Edited by Khasawneh, F. E.; E.C. Sample and E. J. Kamprath. American Society of Agron., Madison.

Sanginga, N. Lyasse and O. B. B. Singh 2000. Phosphorus use efficiency and nitrogen balance of cowpea breeding lines in a low $P$ soil of the derived Savanna zone in West Africa. Plant and Soil 220: 119 - 128.

Santos, A. L. 2000. Some biotic and abiotic factors affecting the production of (Vigna unguiculata, L. Walp.) in Mozambique. Undergraduate Thesis, College of Agric., and Forestry, Maputo.

Shahaby, A. F. 1997. Population dynamics and interaction between cellulose degrading bacteria and diazotrophs in old Nile Valley and newly reclaimed soils. J. Agric. Sci., Mansoura Univ., 22 (12): 4835-4855.

Singh, A. K.; P. N. Tripathi and R. Singh 2007. Effect of Bradyrhizobium inoculation, nitrogen and phosphorus levels on growth, yield and quality of kharif cowpea (Vigna unguiculata, L.) Walp. Crop Res., (Hisar). 33: 1/3, 71-73.

Singh, J. S.; B. N. Singh and T. Singh 2006. Response of cowpea (Vigna unguiculata, L. Walp.) to phosphorus levels and microbial inoculation. Vegetable Sci. 32: 2, 203-204.

Singh, S. and K. K. Kapoor 1999. Inoculation with phosphate-solubilizing microorganisms and visicular-arbuscular mycorrhizal fungus improves dry matter yield and nutrient uptake by wheat grown in sandy soil. Biol. Ferti. Soils, 28: 139-144.

Sivak, D. A. and M. N. Walker 1986. Mineral Nutrition in Vegetables. John Walker, New York.

Snedecor, G. A. and W. G. Cochran 1980. Statistical Methods, $7^{\text {th }}$ Ed., The lowa State Univ., Press, Ames., lowa, U.S.A.

Tyiem, M. N. and S. T. Chieng 2003. Irrigation scheduling effects on yield and phosphorus uptake of cowpea. Ministry of Agric., Nigeria.

Uarrota, V. G. (2010). Response of cowpea (Vigna unguiculata, L. Walp.) to water stress and phosphorus fertilization. J. Agron. 9 (3): 87 - 91. 
Vincent J.M. 1970. A Manual for the practical Study of the Root- nodule Bacteria. IB p.15. Prentice Hall International, Ltd., New Jersey, USA.

Yousry, M.; O. M. Kabesh and M. S. Saber 1987. Manganese availability in a calcareous soil as a result of phosphate fertilization and inoculation with phosohobacterin. African J. Agric. Sci. 5(2):75- 80.

تأثير أستخدام اللقاحات الميكروبية على خفض معدلات الأسمدة المعدنية في نباتـات

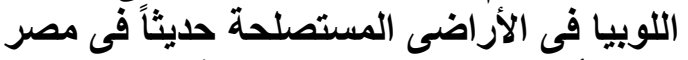

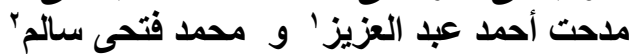

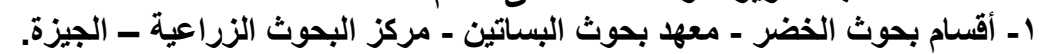

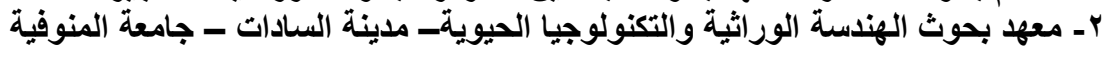

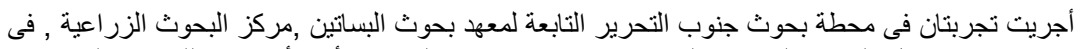

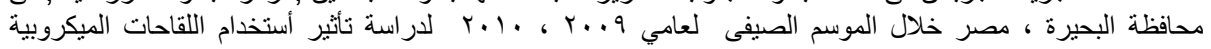

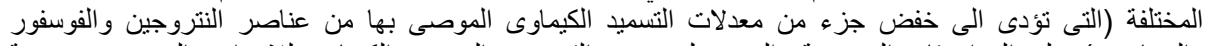

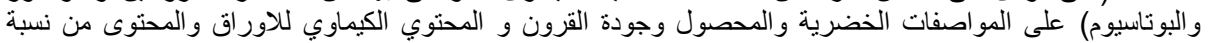

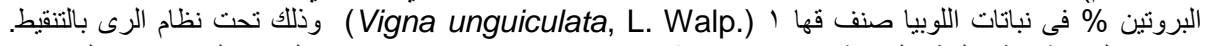

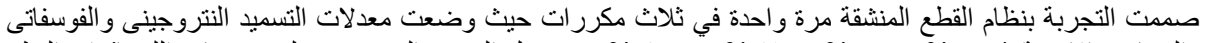

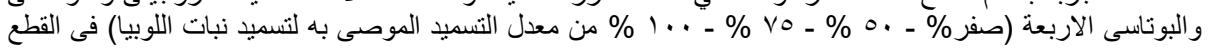
الرئيسية (و الخمس معاملات للبكتريا وهى كما يلى :-

without microbial inoculation (B0), inoculations with Azospirillum sp. and Trichoderma $\mathrm{sp}$. for nitrogen (B1), Bacillus megaterium for phosphorus (B2), Pseudomonas fluorescens for potassium (B3) and the mixtures of all previous of microbial inoculations (B4).

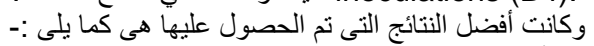

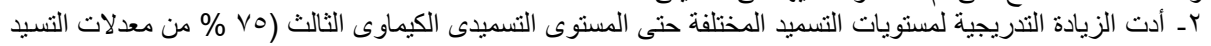

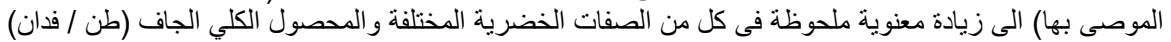

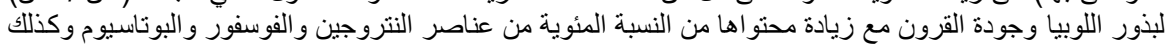

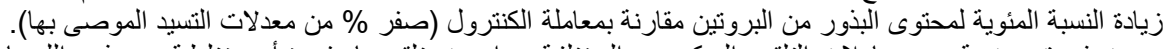

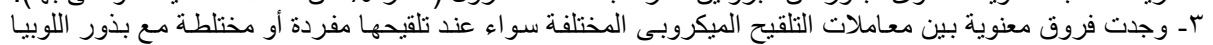

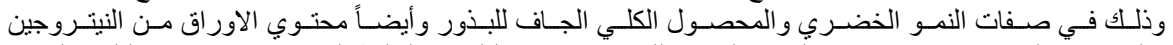

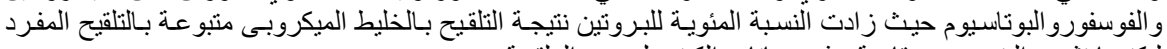

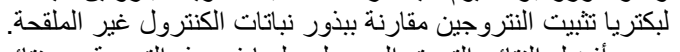

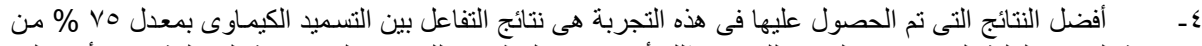

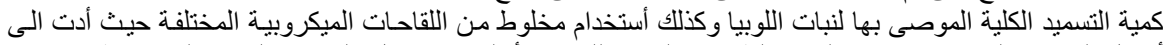

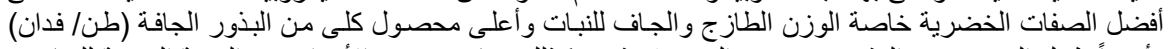

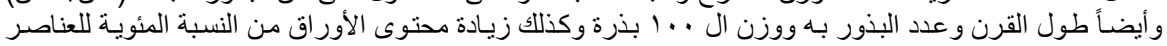

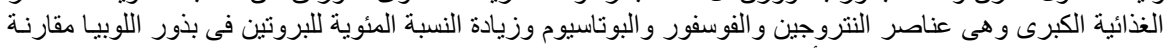

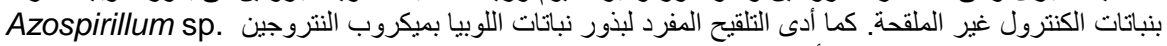
and Trichoderma sp.

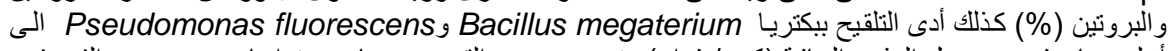

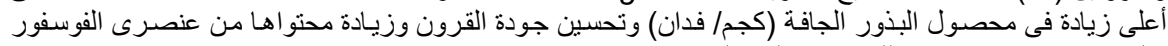
و البوتاسيوم مقارنة بنباتات اللوبيا غير البذور المعاملة. قام بتحكيم البحث

كلية الزراعة - جامعة المنصورة مركز البحوث الزراعيه

أ.د / حسام السعيد عبد النبى زئ أ.د / جمال ابو سته زايد الد النيد 
Abdel-Aziz, M. A. and M. F. Salem 